\title{
Ink still wet on China's nuclear pact with US
}

\section{Washington}

A row is brewing between the US administration and the Congress about the nuclear cooperation agreement with China, signed last week during the visit of President Li Xiannian of the People's Republic of China. The agreement, intended to permit the sale of reactor components and nuclear fuel to China, will offend those in Congress who look for a strict application of the spirit as well as the letter of the Nuclear Non-Proliferation Act (1978). But those who oppose trade with China (as distinct from Taiwan) will also use the occasion to make the administration uncomfortable.

The agreement is the first between the United States and a Communist government, and is also unusual in that it involves a nuclear-weapons state; US agreements with Britain on nuclear collaboration are a kind of precedent, although they have been subsumed for the past 15 years by the accord between the United States and Euratom (which has France as well as Britain as a member). The China pact includes no formal safeguards system, bilateral or multilateral, as required of agreements with non-nuclear-weapons states by the 1978 act. The administration said, when sending the agreement to Congress last week, that China's status as a nuclear power exempts it from requirements of this kind.

It remains to be seen whether Congress will agree. The way the wind is blowing should be clarified at the public hearing arranged for this week (Wednesday) by the Bonker subcommittee of the Foreign Policy Committee of the House of Representatives.

The China pact is important for several reasons, but not least because it is the first bilateral nuclear agreement to have been signed with an overtly Communist state. The Chinese have also made it clear that the sincerity of the US approchement with China will be judged by the administration's capacity to deliver an agreement, while Congress will regard the agreement as a test of the administration's commitment to the non-proliferation cause

The delicacy of the situation is the chief explanation of the delay in signing the

\section{Nature in Washington}

STEPHen Budiansky, Washington Editor of Nature for the past year and a member of the Washington staff for the past three, has joined the Office of Technology Assessment of the US Congress on a one-year congressional fellowship. agreement, initialled as long ago as April 1984, on President Reagan's visit to Beijing. But there have also been rumours, called intelligence reports, that the withdrawal of a Chinese group of nuclear scientists from Pakistan at the turn of the year was a precondition of last week's signing ceremony

Under the Nuclear Non-Proliferation Act, Congress has 90 working days in which to object to the agreement, which means that the issue will be settled only in February 1986. Under the terms of the act, however, Congress has only thirty days to ask the administration to seek a waiver from the strict provisions of the law, which is why the Bonker committee has been so quick off the mark.

A committee staff member said last week that particular attention would be paid to the "non-paper agreements" between the administration and the Chinese government, many of which are classified. One of these is believed to be a memorandum prepared in Washington, shown to the Chinese by Ambassador Richard $\mathrm{T}$. Kennedy, special adviser for nonproliferation affairs at the State Department, but assented to only verbally.

The agreement itself is written as between two equal partners, but is permissive only. The actual supply of reactor components and fuel by US companies will be for later commercial negotiations. The supply of "sensitive" materials and of technology for making weapons is excluded from the agreement.

One of the contentious features of the agreement is the absence of provisions for formal safeguards on nuclear materials supplied to China. The administration says, in the documents sent to Congress with the agreement, that safeguards are not required by current law because China is a nuclear weapons state. But the agreement does allow for visits to nuclear sites to be arranged "through diplomatic channels". The administration says that it will ensure that appropriate arrangements for visits are made before material is actually transferred.

The agreement goes some way to meet fears that materials supplied might be used for military purposes. Apart from the emphasis throughout the text on the peaceful objectives of the cooperation intended, there is a specific provision that materials supplied under the agreement will not "be used for any nuclear explosive device" or even for research to such an end.

The specific requirement of the law that nuclear fuel should neither be further enriched nor reprocessed without prior con- sent has been met in a roundabout fashion. The agreement says that "neither party has any plans ..." to deal in such a way with materials covered by the agreement, but says that requests at a later stage to reprocess nuclear fuel to extract plutonium will be considered favourably.

This clause of the proposed agreement says that there will be a period of six months during which the two governments must seek to negotiate an agreement on re-enrichment or reprocessing, and that the United States will for that period be able to insist that China does not go ahead for fear that it may "prejudge" the outcome. But after six months are up, China may proceed with its plans "on an interim basis".

With the third review conference of the non-proliferation treaty due to begin at Geneva at the end of August, it is inevitable that the agreement will be held up as a weakening of the resolve of the United States to hold back the proliferation of nuclear weapons. The administration, on the other hand, insists that the agreement is entirely in conformity with the law, but also draws attention to recent Chinese statements to the effect that nuclear proliferation is unwelcome. John Maddox

\section{Plans trimmed}

CHINA's nuclear plans have been substantially scaled down from the ambitious programme widely talked of in recent years, according to documents assembled by the US administration in support of the agreement on collaboration with China.

There are three immediate projects in hand: a 300-MW power plant designed in China and being built at Qinshan, Zhejiang, a twin 900-MW reactor station (with Hong Kong participation) at Day Bay, Guangdong and a twin 1,000-MW reactor station at Sunan, on the southern bank of the Yangtze, north of Shangai. All these are light-water reactors.

China's need for nuclear power seems largely determined by geography. Coal, the chief fuel for electricity production, is largely concentrated in the north and in central China, and although production increased by 8 per cent last year, it is not enough to meet demand.

The US Arms Control and Disarmament Agency says that China has enough uranium to support at least a modest nuclear programme, and that there has not yet been enough exploration to determine the full potential of China. China's indigenous nuclear technology is an outgrowth of cooperation with the Soviet Union, which came to an end soon after a Soviet research reactor was installed at the Beijing Institute of Atomic Energy.

According to the agency, there are two other research centres in the Shangai Nuclear Physics Institute and an institute at Chengdu in Sichuan province that is chiefly responsible for reactor design. 